UDC 575+577.1 : 633.1

KARELOV A.V. ${ }^{\bowtie}$, KOZUB N.A., SOZINOV I.A.

Institute of Plant Protection of NAAS of Ukraine,

Ukraine, 03022, Kyiv-22, Vasylkivska str., 33, e-mail: tolikkarelov@meta.ua

凶tolikkarelov@meta.ua,(050)835-17-43

\title{
GENOTYPING OF UKRAINIAN COMMON WHEAT CULTIVARS USING THE MARKER OF THE LR48 GENE CONFERRING MODERATE RESISTANCE TO LEAF RUST
}

Aim. Common wheat (Triticum aestivum L.) is one of the most important and widely cultivated crops over the world. For a lot of wheat diseases introduction of resistance genes is considered to be the most rational way to diminish yield losses and control spread of causal agents. The aim of this research was to study a sample of Ukrainian common wheat cultivars with the use of the molecular genetic marker for the $L r 48$ gene. Methods. DNA samples of 46 common wheat cultivars developed in the Remeslo Myronivka Institute of Wheat (RMIW) of National Academy of Agrarian Sciences jointly with the Institute of Plant Physiology and Genetics of National Academy of Sciences of Ukraine were analyzed with the use of the marker IWB70147. Results. It was revealed that 15 out of 46 (or $32.6 \%$ ) cultivars carried resistance-associated allele of the marker. Conclusions. It was revealed that the resistance-associated allele of the marker of the $\mathrm{Lr} 48$ gene is present in Ukrainian common wheat cultivars developed in the Forrest Steppe zone of Ukraine. The possible source of the resistance allele is 'Mironovskaya 808 ' which is in the pedigree of many Ukrainian and world wheat cultivars. The data obtained in this research can be used in breeding programs to select sources of moderate adult plant resistance. Cultivars 'Yuviliar Myronivskii', 'Volodarka' and 'Pamyati Remesla' with adult leaf rust resistance conferred by the $\operatorname{Lr} 48$ gene also carry resistance associated allele of the Lr34/Yr18/Pm38/Sr57/Bdv1 gene.

Keywords: molecular markers, wheat, resistance genes, adult plant resistance.

Common wheat (Triticum aestivum L.) is one of the most important and widely cultivated crops over the world [1]. For a lot of wheat diseases introduction of resistance genes is considered to be the most rational way to diminish yield losses and control spread of causal agents [2,3]. So genetic basic and new sources of resistance are of concern to scientists and breeders [4-6]. One of the most widespread fungal diseases of wheat is leaf or brown rust (the causal agent is Puccinia triticina Erikss.) [5-7]. In a number of studies, the genetic background of race specific resistance against leaf rust was revealed [8-10]. Although this type of resistance can be easily detected in the field and significantly reduces the disease symptoms, it is not durable for a prolonged period of time: for the majority of known genes conferring race specific resistance virulent races eventually emerged $[6,11]$. Adult leaf rust resistance genes are on the other hand far less conspicuous in field and confer only a moderate level of resistance, however races of $P$. triticina virulent to most of known adult plant resistance genes have not been discovered yet [6]. Both kinds of leaf rust resistance genes are used in modern breeding strategies like "pyramiding" and "marker-assisted selection" $[12,13]$.

Molecular genetic markers of adult plant resistance gene Lr34/Yr18/Pm38/Sr57/Bdv1 [14], tan spot (in)sensitivity genes $T s n 1$ and $T s c 2$ [15] and Fusarium head blight resistance gene TDF_076_2D [16] were used for genotyping of Ukrainian common wheat cultivars. As a result of the statistical processing of the obtained data the correlation suggesting a major quantitative trait locus on chromosome 2BS conferring durable field leaf rust resistance was revealed [17]. One of the possible genes located on chromosome 2BS and being able to confer such a resistance is gene $\operatorname{Lr} 48$ [17].

Gene $L r 48$ was first described as a race specific resistance gene [18]. Further research, howev$\mathrm{er}$, revealed the nature of resistance conferred by the gene as moderate and adult [19]. The gene was mapped with use of SSR markers, although in different publications it is localized either on the long arm of chromosome $2 \mathrm{~B}[18,19]$ or on the short one [20]. The latest and the most durable set of markers was developed to use KASP technique; in this research the gene was once again localized on chromosome 2BS; among the markers used IWB70147 was considered to be the most accurate [17].

The aim of this research was to study a sample of Ukrainian common wheat cultivars with the use

\footnotetext{
${ }^{\circ}$ KARELOV A.V., KOZUB N.A., SOZINOV I.A.
} 
of the molecular genetic marker for the $L r 48$ gene.

\section{Materials and methods}

DNA extracted from seeds of 46 wheat cultivars developed in the Remeslo Myronivka Institute of Wheat (RMIW) of National Academy of Agrarian Sciences jointly with the Institute of Plant Physiology and Genetics of National Academy of Sciences of Ukraine were analyzed. The complete list of the cultivars is shown in table. For DNA extraction the samples of $25-30 \mathrm{mg}$ obtained from grinding 5-7 seeds were used. Further procedure included the use of the Diatom TM DNA Prep100 DNA isolation kit (the sales representative in Ukraine is Neogene ${ }^{\circledR}$ Company) according to the standard protocol. PCR was performed using GenPak® PCR Core Kits (the sales representative in Ukraine is Neogene ${ }^{\circledR}$ Company) according to the manufacturer's recommendations. The primers flanking the marker IWB70147 used in this study were the following: IWB70147_F2 (5'cgecctacaccettatgtacc3') and IWB70147_R (5'taccaatctagagtaacattaccgccaaa3') [18]. PCR was performed according to the following protocol: previous denaturation and Hot Start DNA-polymerase activation at $94^{0} \mathrm{C}$ for 6 min.; 32 cycles including denaturation at $94^{\circ} \mathrm{C}$ for $50 \mathrm{~s}$, annealing at $63^{\circ} \mathrm{C}$ for $25 \mathrm{~s}$ and elongation at $72^{\circ} \mathrm{C}$ for $30 \mathrm{~s}$; final elongation at $72^{\circ} \mathrm{C}$ for $5 \mathrm{~min}$. The amplified fragments in case of the resistance-associated allele of the marker were $\sim 62 \mathrm{bp}$ in length (further marked as '+', see Fig. and table) and no amplified fragments were expected to obtain otherwise (further marked as '-', see Fig. and table) [17].

PCR results were visualized by electrophoresis in 2-2.5\% agarose gel in $0.5 \times$ TBE buffer with subsequent staining with ethidium bromide and use of the gel-visualization system VISION Gel (Fig.).

\section{Results and discussion}

The marker used in this research was originally developed for the KASP technique [17]. Complementary to the resistance-associated allele primer IWB70147_F1 with common primer IWB70147_R were successfully used as a marker for conventional PCR (fig.). The primer IWB70147_F1 complementary to the allele '-' in combination with the IWB70147_R primer did not reveal any polymorphism among the cultivars tested (data not shown). So in this research IWB70147 was used as a dominant conventional PCR marker (fig.).

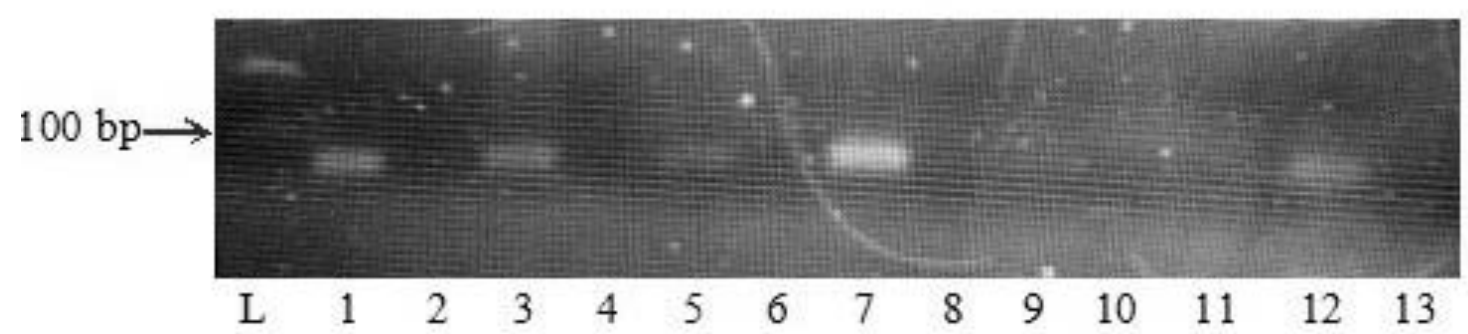

Fig. Example of PCR products with the primers flanking the marker IWB70147. The samples used in PCR are following: 1 - 'Myronovskaya 808'; 2 - 'Thatcher'; 3 - 'Dobirna'; 4 - 'Oberig Myronivskii'; 5 - 'Lasunia'; 6 - 'Myrlena'; 7 - 'Khazarka'; 8 - 'Kolumbiya'; 9 - 'Bohdana', 10 - 'Snigurka'; 11 - 'Ukrainka'; 12 - 'Yasnogirka'; 13 - 'Madyarka'; $\mathrm{L}-100$ bp ladder.

According to the data on the allelic state of the marker IWB70147 for the cultivars studied, the resistance conferred by the $L r 48$ gene is quite common at least for the wheat varieties developed in the Forrest Steppe zone of Ukraine (table).

It was revealed that 15 out of 46 (or $32.6 \%$ ) cultivars tested carried the ' + ' allele of the marker (table). Among the cultivars with the resistance allele of the gene is 'Mironovskaya 808' known to be in the pedigree of many Ukrainian and European common wheat cultivars [21]. The cultivars 'Yuviliar Myronivskii', 'Volodarka' and 'Pamyati Remesla' with the allele '+' of the marker IWB70147 have been found to carry resistance allele of the Lr34/Yr18/Pm38/Sr57/Bdvl gene as well [14], making them useful in breeding aimed at "pyramiding" of leaf rust resistance factors [12]. Besides that, 'Volodarka' carries alleles of the Tsn1 and Tsc2 genes associated with insensitivity to toxins Pyrenophora tritici-repentis (Died.) Drechsler, (1923) [15]. In addition, 'Yasnogirka', 'Myronivska 28', 'Svitanok Myronivskii' and 'Zolotokolosa' besides the ' + ' allele of the marker IWB70147 also carry alleles of the $T s n 1$ and $T s c 2$ genes associated with insensitivity to toxins $P$. tritici-repentis [15]. 
Table. Allelic state of the marker $I W B 70147$ for gene Lr48 in a sample of Ukrainian common wheat cultivars

\begin{tabular}{|l|l|l|l|l|l|}
\hline \multicolumn{1}{|c|}{ Cultivar name } & $\begin{array}{c}\text { Allelic } \\
\text { state of the } \\
\text { marker } \\
\text { IWB70147 }\end{array}$ & \multicolumn{1}{|c|}{ Cultivar name } & $\begin{array}{c}\text { Allelic } \\
\text { state of the } \\
\text { marker } \\
\text { IWB70147 }\end{array}$ & \multicolumn{1}{|c|}{ Cultivar name } & $\begin{array}{c}\text { Allelic } \\
\text { state of the } \\
\text { marker } \\
\text { IWB70147 }\end{array}$ \\
\hline Bohdana & - & Myronivska 264 & + & Pereyaslavka & - \\
\hline Demetra & - & Myronivska 27 & - & Podolianka & - \\
\hline Dobirna & + & Myronivska 28 & + & Pyvna & - \\
\hline Dostatok & + & Myronivska 29 & - & Smuglianka & - \\
\hline Ekspromt & - & Myronivska 31 & - & Snigurka & - \\
\hline Favorytka & - & Myronivska 33 & - & Snizhana & - \\
\hline Khazarka & + & Myronivska 61 & - & Sviatkova & - \\
\hline Khurtovyna & - & Myronivska 65 & - & $\begin{array}{l}\text { Svitanok Myro- } \\
\text { nivskii }\end{array}$ & + \\
\hline Kolos Myronivshchyny & - & Myronivska 66 & + & Ukrainka & - \\
\hline Kolumbiya & - & Myronivska 67 & - & Vesnianka & + \\
\hline Kryzhynka & - & Myronivska rannios- \\
tygla & Myronivska Storichna & - & Vesta & \\
\hline Lasunia & - & Myronovskaya 808 & + & Volodarka & + \\
\hline Legena Myronivshchyny & - & Oberig Myronivskii & - & Yasnogirka & + \\
\hline Madyarka & - & Pamyati Remesla & & $\begin{array}{l}\text { Yuviliar } \\
\text { nivskii }\end{array}$ \\
\hline Myrlena & & & Zolokolosa & + \\
\hline
\end{tabular}

\section{Conclusions}

It was revealed that the resistance-associated allele of the marker of the $L r 48$ gene is present in Ukrainian common wheat cultivars developed in the Forrest Steppe zone of Ukraine. The possible source of the resistance allele is 'Mironovskaya 808' which is in the pedigree of many Ukrainian and world wheat cultivars. The data obtained in this research can be used in breeding programs to select sources of moderate adult plant resistance. Cultivars 'Yuviliar Myronivskii', 'Volodarka' and 'Pamyati Remesla' with adult leaf rust resistance conferred by the $L r 48$ gene also carry resistance associated allele of the $L r 34 / Y r 18 / P m 38 / S r 57 / B d v 1$ gene.

\section{References}

1. Bushuk W., Rasper V.F. (eds.) Wheat: production properties and quality. Blackie/Chapman and Hall, London, 1994. 239 p.

2. Johnson R. Past, present and future opportunities in breeding for disease resistance, with examples from wheat. Euphytica. 1992. Vol. 63, Iss. 1-2. P 3-22.

3. Sharma I. (ed.) Disease Resistance in Wheat. Hardback, Punjab Agricultural University, India, 2012. 336 p.

4. Langridge P., Lagudah E.S., Holton T.A., Appels R., Sharp P.J., Chalmers K.J. Trends in genetic and genomic analyses in wheat: A Review. Australian J Agric Res. 2001. Vol. 52. P. 1043-1078.

5. Lesser W., Kolady D.E. Disease Resistance of Wheat Varieties: Can Private Varieties Withstand the Pressure? Economics Research International. 2011. Vol. 2011. 6 p. URL: http://dx.doi.org/10.1155/2011/575192 (Last accessed: 1.03.2018).

6. Ellis J.G., Lagudah E.S., Spielmeyer W., Dodds P.N. The past, present and future of breeding rust resistant wheat. Frontiers in Plant Science. 2014. Vol. 5, Iss. 641. URL: http://dx.doi:10.3389/fpls.2014.00641 (Last accessed: 1.03.2018).

7. Bolton M.D., Kolmer J.A., Garvin D.F. Wheat leaf rust caused by Puccinia triticina. Mol Plant Pathol. 2008. Vol. 9, Iss. 5. P. 563-575. 
8. Gupta V.S., Khan R.R., Rajwade A.V., Reddy, D.M.R., Hosmani P., Dholakia B.B., Lagu M.D., Tamhankar S.A., Rao V.S., Sain, R.G. Molecular Mapping of Leaf Rust Resistance Gene Lr15 in Bread Wheat. 11th Int. Wheat Genet. Symp. Sydney: Univ. press, 2008. P. 724-726.

9. Cloutier S., McCallum B.D., Loutre C., Banks T.W., Wicker T., Feuillet C., Keller B., Jordan M.C. Leaf rust resistance gene Lrl, isolated from bread wheat (Triticum aestivum L.) is a member of the large psr567 gene family. Plant Mol Biol. 2007. Vol. 65, Iss. 1-2. P. 93-106.

10. Huang L., Brooks St.A, Li W., Fellers J.P., Trick H.N., Gill B.S. Map-based cloning of leaf rust resistance gene $L r 21$ from the large and polyploid genome of bread wheat. Genetics. 2003. Vol. 164, Iss. 2. P. 655-664.

11. Kolmer J.A. Genetics of resistance to wheat leaf rust. Annu Rev. Phytopathol. 1996. Vol. 34. P. 435-455.

12. Boskovic J., Boskovic M., Babovic M., Jerkovic Z., Pesic V. Pyramiding Strategy for Durable Resistance to Wheat Leaf Rust Pathogen. Wheat in a Global Environment. Developments in Plant Breeding / Bedö Z., Láng L. (eds). 2001. Vol. 9. P. 337-343.

13. Collard B.C., Mackill D.J. Marker-assisted selection: an approach for precision plant breeding in the twenty-first century. Philosophical Transactions of the Royal Society B: Biological Sciences. 2008. Vol. 363 (1491). P. 557-572.

14. Karelov A.V., Pirko Ya.V., Kozub N.A., Sozinov I.A., Pirko N.N., Litvinenko N.A., Lyfenko S.F., Koliuchii V.T., Blume Ya.B., Sozinov A.A. Identification of the allelic state of the Lr34 leaf rust resistance gene in soft winter wheat cultivars developed in Ukraine. Cytology and Genetics. 2011. Vol. 45, No. 5. P. 3-10.

15. Karelov A.V., Kozub N.A., Sozinov I.A., Sozinov A.A., Blume Ya.B. Allelic state of the molecular genetic markers for genes associated with sensitivity to Pyrenophora tritici-repentis toxins A and B and Staganospora nodorum toxin A among Ukrainian common wheat cultivars. The Bulletin of Vavylov Society of Geneticists and Breeders of Ukraine. 2015. Vol. 13, No. 1. P. 11-17.

16. Karelov A.V., Kozub N.A., Sozinov I.A., Borzykh A.I. Polymorphism of the TDF_076_2D gene conferring moderate Fusarium head blight resistance among common wheat (Triticum aestivum L.) cultivars of the steppe zone of Ukraine. Scientific reports of NULES of Ukraine. 2015. No. 2 (51). URL: http://nd.nubip.edu.ua/2015_2/7e.pdf (Last accessed: 02.28.2018).

17. Nsabiyera V., Qureshi N., Bariana H.S., Wong D., Forrest K.L., Hayden M.J. Molecular markers for adult plant leaf rust resistance gene Lr48 in wheat. Molecular Breeding. 2016. Vol. 36, Iss. 65. doi: https://doi.org/10.1007/s11032-016-0488-5.

18. Saini R.G. Kaur M., Singh B., Sharma S., Nanda G.S., Nayar S.K, Gupta A.K., Nagarajan S. Genes Lr48 and Lr49 for hypersensitive adult plant leaf rust resistance in wheat (Triticum aestivum L.). Euphytica. 2002. Vol. 124. P. 365-370.

19. Bansal U.K., Hayden M.J., Venkata B.P., Khanna R., Saini R.G., Bariana H.S. Genetic mapping of adult plant leaf rust resistance genes Lr48 and Lr49 in common wheat. Theor Appl Genet. 2008. Vol. 117, Iss. 3. P. 307-312.

20. Singh A., Pallavi J.K., Gupta P., Prabhu K.V. Identification of microsatellite markers linked to leaf rust adult plant resistance (APR) gene Lr48 in wheat. Plant Breeding. 2011. Vol. 130, Iss. 1. P. 31-34.

21. GRIS: Genetic Resources Information System for Wheat and Triticale (database). URL: http://www.wheatpedigree.net/ (Last accessed: 02.28.2018).

КАРЕЛОВ А.В., КОЗУБ Н.О., СОЗІНОВ І.О.

Інститут захисту рослин НААН Украӥни,

Україна, 03022, м. Київ-22, вул. Васильківська, 33, e-mail: tolikkarelov@meta.иа

\section{ГЕНОТИПУВАННЯ СОРТІВ ПШЕНИЦІ М'ЯКОЇ УКРАЇНСЬКОЇ СЕЛЕКЦІЇ ЗА ДОПОМОГОЮ МА- PКЕРА ГЕНА LR48, ЩО ЗАБЕЗПЕЧУЄ ПОМІРНУ СТІЙКІСТЬ ДО БУРОЇ ІРЖІ}

Mema. Пшениця м'яка (Triticum aestivum L.) є однією з найбільш важливих і широко вирощуваних сільськогосподарських культур у світі. Для багатьох хвороб пшениці впровадження генів стійкості вважають найраціональнішим шляхом зменшити втрати урожаю ї контролювати поширення збудників. Метою цього дослідження було вивчення вибірки сортів пшениці м’якої української селекції за допомогою маркера гена Lr48. Meтоди. Зразки ДНК 46 сортів пшеницы мёякої створених у Миронівському інституті пшениці ім. Ремесла Національної академії аграрних наук України разом із Інститутом фізіології рослин і генетики Національної академії наук України були досліджені за допомогою маркера IWB70147. Результати. Було виявлено, що 15 з 46 (або 32,6 \%) сортів несуть асоційований зі стійкістю алель маркера. Висновки. Було виявлено, що асоційований зі стійкістю алель маркера гена $L r 48$ присутній у сортів пшениці м'якої, створених у лісостеповій зоні України. Можливим джерелом алеля стійкості є Миронівська 808 , яка зустрічається у родоводах багатьої українських і світових сортів. Дані, отримані в цьому дослідженні, можуть бути використані в селекційних програмах для вибору джерел помірної дорослої стійкості. Сорти Ювіляр Миронівський, Володарка і Пам'яті Ремесла із дорослою стійкістю, яку забезпечує ген Lr48 також несуть пов'язаний зі стійкістю алель гена Lr34/Yr18/Pm38/Sr57/Bdv1.

Ключові слова: молекулярні маркери, пшениці, гени стійкості, доросла стійкість рослин. 